formation by an arbitrary figure-conventionally $25 \%$-it has been postulated that the lymphocyte donor is immunosuppressed. In contrast normal immunological reactivity is claimed to be present when the amount of antihuman lymphocyte globulin needed for rosette inhibition is the same as that required for the cells of normal people.

We studied severely burnt patients during a period when cell mediated immunity is known to be depressed. If the M.I.C. is a direct index of cell mediated immunological reactivity it would be expected that tests on the cells of such patients would show inhibition with low amounts of antihuman lymphocyte globulin. The results presented show that this is not the case. In $76 \%$ of the tests performed normal or greater than normal amounts of antihuman lymphocyte globulin were required. Some of the patients (none of whom had had live allografts and in whom there was no question of rejection) required normal or increased amounts of antihuman lymphocyte globulin to inhibit rosette formation. These included burned and non-burned patients, and it is therefore evident that factors other than rejection must influence the minimal dose of antihuman lymphocyte globulin required.

Changes in M.I.C. have been correlated with the ratio of sodium to potassium in the urine. The ratio of electrolytes excreted in the urine is known to be affected by adrenal cortical hormones (Stoner, 1969). A variety of pathological processes including trauma and infection may affect the urinary sodium to potassium ratio; the exact mechanism is not known but the adrenal glands are thought to play a part (Stoner, 1969). This suggests that the change in M.I.C. reflects non-specific pathological processes. When cells are preincubated with plasma from burnt or non-burnt patients or hydrocortisone more antihuman lymphocyte globulin is required to inhibit rosette formation. It is therefore possible that the plasma steroid hormone levels are a major factor influencing the results of this test. It might, however, be difficult to correlate cortisol levels with M.I.C. since though the half life of cortisol in the circulation is one to three hours the maximum effects occur two to eight hours later (Laurence, 1966).

To ascertain conclusively whether rejection is specifically associated with a change in M.I.C. skin-grafted patients are being used, since the time and diagnosis of rejection of skin is definite. We have not yet completed this investigation but preliminary results suggest that a patient may reject a skin graft (14-6 cm) without a change in M.I.C.

We are grateful to the late Dr. Pamela Hinton and the staff of the MoIndoe Research Unit for their help and encouragement during this study, and Dr. Stephen Elkington and the physicians of King's College Hospital, London, for permission to include their patients. We also thank Miss Linda Daley for her excellent technical help, Mrs. B. Muller for typing the manuscript, and the East Grinstead Research Trust and the Medical Research Council for financial support.

\section{References}

Bach, J. F., and Antoine, B. (1968). Nature, 217, 658.

Bach, J. F., Dardenne, M., Dormont, J., and Antoine, B. (1969). Transplantation Proceedings, 1, 403.

Batchelor, J. R., and Hacket, M. (1970). Lancot, 2, 581.

Bewick, M., Ogg, C. S., Parsons, V., Snowdon, S. A., and Manuel, L. (1972). British Medical fournal, 3, 491.

Chambler, K., and Batchelor, J. R. (1969). Lancet, 1, 16.

Chapel, H. M. (1972). Lancet, 2, 882.

Chapel, H. M. (1973). Transplantation, 15, 320

Cullum, P. A et al. (1972). British Medical fournal, 2, 71

Daniels, J. C., et al. (1970). Surgery, Gynaecology and Obstetrics, 130, 783. tarris, $R$., et al. (1970). Surgery, Gy

Harris, R., and Ukaejiofo, E. O. (1969). Lancet, 2 , 327. Medicine, 136, G.,

Laurence, D. R. (1966). Clinical Pharmacology, p. 143. London, Churchill Mahler, D., and Batchelor, J. R. (1971). Transplantation, 12, 409.

Munro, A., et al. (1971). British Medical fournal, 3, 271

Munster, A. M., Eurenius, K., Mortensen, R. F., and Mason, A. D. (1972). Transplantation, 14, 106

Rapaport, F. T., and Converse, J. M. (1966). In Research in Burns, ed. A. B. Wallace and A. W. Wilkinson, p. 407. Edinburgh, Livingstone.

Sakai, H., Lynch, J. B., Lewis, S. R., and Ritzmann, S. E. (1972). Meeting of Burn Association, California.

Stoner, H. B. (1969). Annals of the Royal College of Surgeons of England, $44,308$.

\title{
Parents of Battered Babies: A Controlled Study
}

\author{
SELWYN M. SMITH, RUTH HANSON, SHEILA NOBLE
}

British Medical fournal, 1973, 4, 388-391

\section{Summary}

A controlled investigation of 214 parents of battered babies shows that they were young and predominantly of lower social class. Premature parenthood is an associated feature. Among the mothers $76 \%$ had an abnormal personality and $48 \%$ were neurotic. Nearly half were of borderline or subnormal intelligence; $11 \%$ had a criminal record. Of the fathers $64 \%$ had an abnormal personality, more than half being psychopaths. Twentynine per cent. had a criminal record. Recidivism is an associated feature.

\footnotetext{
Department of Psychiatry, Queen Elizabeth Hospital, University of Birmingham, Birmingham B15 2TH

SELWYN M. SMITH, M.B., M.R.C.PSYCH., Lecturer in Psychiatry RUTH HANSON, B.A., Senior Research Associate SHEILA NOBLE, M.A., Senior Research Associate
}

The risk of battering possibly diminishes with time. The teaching of appropriate child-rearing skills, symptomatic relief, and social relearning are suggested as realistically based treatment methods and should be combined with a care order. When response to treatment appears unlikely permanent removal from parental care should be considered.

\section{Introduction}

Though generalizations describing the characteristic features of parents who batter babies have recently become prominent there is a scarcity of controlled studies. Recent observations have suggested that battering parents are not confined to any particular personality type, intelligence level, or social class (Steele and Pollock, 1968) and that "child abuse is psychodynamically related and has nothing to do with race, colour, creed, sex, income, education, or anything else" (Kempe, 1969). By way of contrast other authors have noted that battering parents are young (Gil, 1968) and from the lower social classes (Young, 1964; Skinner and Castle, 1969). Mental illness, 
psychopathy, and subnormality have been observed by several authors (Woolley and Evans, 1955; Birrell and Birrell, 1968; Lukianowicz, 1971). In addition Gibbens and Walker (1956) mention that criminality and alcoholism are often found.

Because we believe that a knowledge of the parental characteristics of baby batterers is of prime importance in the management of the battered baby syndrome and because previous studies have led to conflicting conclusions it was decided to undertake a controlled investigation of battered children and their parents. This paper compares age, class, psychiatric state, criminality, and intelligence in 214 parents of battered babies and 76 control parents.

\section{Subjects and Methods}

\section{INDEX CASES}

Over a two-year period 134 battered infants and children aged under 5 years and their parents were studied in detail. Most children had been admitted to hospitals. All the parents who had either confessed to inflicting trauma or had inadequately explained their child's injuries were referred by the consultant paediatrician to whom the child first came to notice.

\section{CONTROL GROUP}

The controls comprised 53 children admitted to hospital as emergencies. Accident and trauma cases were excluded. Parents of these children were matched with the index group on the basis of mother's age and age of infant. The following variables were held constant: consultants referring cases; area of origin; research team; and the particular circumstances of the involvement of parents in research when their children suddenly and unexpectedly became ill.

In both groups parents were seen as soon as possible after their child's admission to hospital and their co-operation was requested in a research study into the background of children with injuries or conditions similar to that of their own child. All parents underwent standardized psychiatric, psychological, and social interviews.

\section{CLASSIFICATION}

Personality diagnosis was classified on the basis of the American Psychiatric Association classification (1952) into normal and abnormal. Abnormality of personality was further subdivided into mild, moderate, and severe.

Mild (character disorder).-Personality is disordered to the extent that the person is dissatisfied with the quality of his relationship with other people. Such persons may think they cannot make satisfying contacts with others owing to emotional inhibition, dependence on others, or because of their own overbearing behaviour.

Moderate (personality disorder).--Impaired personal relationships are sufficiently noticeable to be evident to others. Such persons are perceived as unusual, odd, or eccentric.

Severe (psychopathic).-Personality disorder is so gross that the subject harms others either through commission of aggressive acts or through omission of ordinary obligations. Thus psychopaths may be classified as aggressive or inadequate. Their work record is often poor (Walton and Presly, 1973).

\section{OTHER FACTORS}

Neurosis was diagnosed at psychiatric interview and classified according to the International Classification of Disease (W.H.O., 1968). Non-psychotic disturbance was measured by the General Health Questionnaire (Goldberg, 1972). Subjects scoring 12 or over on this scale have a high probability of being diagnosed as abnormal. Neuroticism (instability) was measured by the Eysenck Personality Inventory (Eysenck and Eysenck, 1964).

Four subtests of the Wechsler Adult Intelligence Scale (Wechsler, 1955) were given (vocabulary, block design, comprehension, and picture arrangement).

The Criminal Records Office was searched for the names of parents interviewed.

\section{Results}

Age. - The mean age of index mothers was 23.5 years, a high proportion of whom were aged 21 at the time of the child's injury (fig. 1). The mean age of index fathers was 27.0 years, and their age distribution was similar to the mothers.

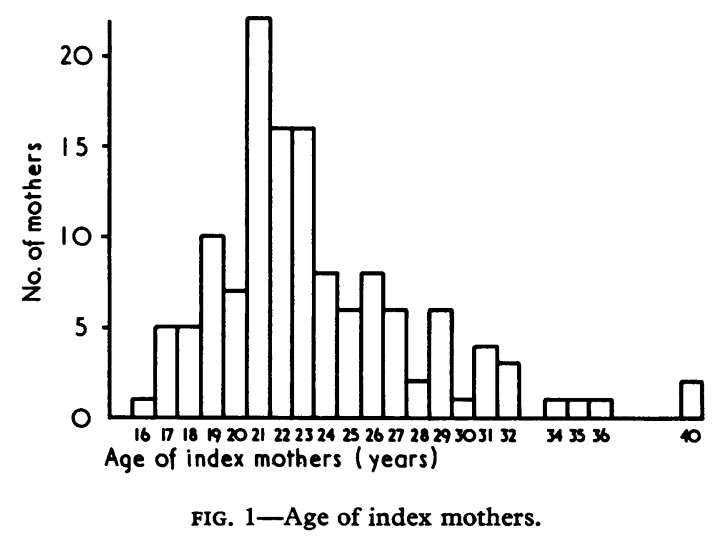

Social Class.-It was found that index group cases were of significantly lower so:ial class than the controls $(P<0.001)$. Among the index parents none came from social class I and only three were from social class II (table I).

Personality.-Ninety-five of the 125 mothers (76\%) and 57 of the 89 fathers $(64 \%)$ in the index group had an abnormal personality. Compared with the controls this amount of abnormality is highly significant $(\mathrm{P}<0.001)$ (table II).

TABLE I-Social Class Distribution among Index and Control Groups

\begin{tabular}{l|c|c|c|c|c}
\hline & I & II & III & IV & V \\
\cline { 2 - 5 } & & \multicolumn{2}{|c|}{$($ Non-Manual) } & \multicolumn{2}{|c}{ (Manual) } \\
\hline $\begin{array}{l}\text { Index group (\%) } \\
\text { Control group (\%). }\end{array}$ & $\begin{array}{l}0(0) \\
5(9 \cdot 6)\end{array}$ & $\begin{array}{l}3(2 \cdot 5) \\
4(7 \cdot 7)\end{array}$ & $\begin{array}{l}26(22) \\
26(50 \cdot 0)\end{array}$ & $\begin{array}{c}56(47 \cdot 5) \\
14(26 \cdot 9)\end{array}$ & $\begin{array}{c}33(28 \cdot 0) \\
3(5 \cdot 8)\end{array}$ \\
\hline
\end{tabular}

$\chi^{2}$ with 1 D.F. $=26 \cdot 29, P<0 \cdot 001$

TABLE II-Comparison of Personality Findings in Parents in Both Groups

\begin{tabular}{|c|c|c|c|c|c|}
\hline & \multicolumn{2}{|c|}{ Normal } & \multicolumn{2}{|c|}{ Abnormal } & \multirow{2}{*}{ Significance } \\
\hline & No. & $\%$ & No. & $\%$ & \\
\hline $\begin{array}{l}\text { Index Mothers } \\
\text { Control mothers } \\
\text { Index fathers } \\
\text { Control fathers }\end{array}$ & $\begin{array}{l}30 \\
44 \\
32 \\
21\end{array}$ & $\begin{array}{l}24 \cdot 0 \\
86 \cdot 3 \\
36 \cdot 0 \\
87 \cdot 5\end{array}$ & $\begin{array}{r}95 \\
7 \\
57 \\
3\end{array}$ & $\left.\begin{array}{l}76 \cdot 0 \\
13 \cdot 7 \\
64 \cdot 0 \\
12 \cdot 5\end{array}\right\}$ & $\begin{array}{c}x^{2}=55.12, \text { D.F. }=1, \\
P<0.001 \text { D.F. }=1, \\
x^{2}=18.15, \text { D.F. } \\
P<0.001\end{array}$ \\
\hline
\end{tabular}

Severity of Personality Disorder.-Seventy-eight (62.4\%) of mothers had personality disorders of mild or moderate severity compared with the controls. This is a significant finding (for 1 D.F. and $\left.\chi^{2}=45.32, \mathrm{P}<0.001\right)$. Twenty-four (27\%) of fathers had mild or moderately severe personality disorders and this also was significantly different from the controls (for 1 D.F. and $\left.\chi^{2}=5.63, P<0.05\right)$. Seventeen mothers $(13.6 \%)$ and 33 fathers 
$(37 \cdot 1 \%)$ in the index group had severe personality or psychopathic disorders. None of the controls were psychopathic. Nine mothers $(7.2 \%)$ and 29 fathers $(32.6 \%)$ were aggressive psychopaths. Eight mothers $(6.4 \%)$ and four fathers $(4.5 \%)$ were inadequate psychopaths. Alcoholism and drug dependence were not features among the index cases or controls.

Neurosis.-Among the index group 60 mothers (48\%) and 9 fathers $(10 \cdot 1 \%)$ were neurotic. Compared with the controls neurosis was a significant finding $(P<0.001)$ among index mothers only (table III). Of the index mothers $34(27 \cdot 2 \%)$ showed mixed neurotic symptomatology, 21 (16.8\%) were depressed, $2(1.6 \%)$ showed anxiety reactions, and $2(1.6 \%)$ had hysterical reactions. One subject $(0.8 \%)$ was agoraphobic. Of the control mothers $5(9.8 \%)$ showed a mixed neurotic picture. One index mother had anorexia nervosa. She starved one child to death and battered another who was older. Her case has been described in detail elsewhere (Smith and Hanson, 1972).

TABLE III-Comparison of Neurosis Findings in Index Mothers and Controls

\begin{tabular}{|c|c|c|c|c|c|}
\hline & & \multicolumn{2}{|c|}{ Non-Neurotic } & \multicolumn{2}{|c|}{ Neurotic } \\
\hline & & No. & $\%$ & No. & $\%$ \\
\hline $\begin{array}{l}\text { Index group } \\
\text { Control group }\end{array}$ & $\ldots$ & $\begin{array}{l}65 \\
46\end{array}$ & $\begin{array}{l}52 \cdot 0 \\
90 \cdot 2\end{array}$ & $\begin{array}{r}60 \\
5\end{array}$ & $\begin{array}{r}48.0 \\
9.8\end{array}$ \\
\hline
\end{tabular}

General Health Questionnaire.-Index mothers had a mean score of $19 \cdot 2$. They scored 12 plus significantly more often (1 D.F. and $\chi^{2} 8.37, P<0.01$ ) than the controls. For other groups the mean scores were normal (index fathers, 11.0 ; control mothers, $7 \cdot 2$; control fathers, $6 \cdot 1$ ). This finding supports the validity of clinical diagnosis of neurosis found among the index mothers (mentioned above).

Eysenck Personality Inventory.-High scoring (20 plus) on the neuroticism $(\mathrm{N})$ scale of the inventory is significantly more characteristic of index than control mothers (for 1 D.F. and $\chi^{2}$ 4.69, $\mathrm{P}<0.05$ )

Psychosis.-Psychotic reactions were observed in four mothers $(3.2 \%)$ and one father $(1 \cdot 1 \%)$. None of the controls were psychotic. Two mothers were paranoid schizophrenics; one of them killed her two children under the influence of hallucinations. She was found unfit to plead and committed to a special hospital. Two mothers and one father were psychotically depressed. The injuries inflicted on the children by psychotic parents were bizarre.

Criminal Records.-Excluding Juvenile Court appearances among the index group $29.2 \%$ of the fathers and $11.2 \%$ of the mothers had a criminal record (table IV). Of the control group none of the mothers and only two of the fathers had a criminal record. After the child abuse incident subsequent criminal convictions for offences other than child abuse occurred in $6.7 \%$ of fathers and $4 \%$ of mothers. Twenty-three fathers $(25.8 \%)$ and 13 mothers $(10.4 \%)$ in the index group had been convicted for theft or larceny (table V). Convictions for violent crimes were recorded in eight fathers $(9.0 \%)$ and one mother $(0.8 \%)$. Four of the fathers $(4.5 \%)$ had convictions for sexual offences including rape. Cruelty and neglect to children were recorded in only one mother and one father.

Intelligence.-The mean I.Q.s (based on the combined subtests) were $\mathbf{8 0}$ for index mothers, 95 for controls, 92 for index fathers, and 102 for controls. The difference in distribution of I.Q.s between index and control mothers is highly significant (for 2 D.F. $\chi^{2}=28.61, P<0.001$ ). Index and control fathers were also different in ability but the difference was not as statistically significant. The distribution of mothers' I.Q.s are shown in fig. 2. Nearly half the sample of index mothers were of borderline subnormality or below.
TABLE IV-No. of Parents with Criminal Records in Index Group

\begin{tabular}{|c|c|c|c|c|}
\hline & & $\begin{array}{c}\text { No. of } \\
\text { Criminal Records } \\
\text { Investigated }\end{array}$ & $\begin{array}{c}\text { No. with } \\
\text { Criminal Records } \\
\text { after Child } \\
\text { Abuse Incident }\end{array}$ & $\begin{array}{l}\text { Total No. } \\
\text { with Criminal } \\
\text { Records }\end{array}$ \\
\hline $\begin{array}{l}\text { Fathers } \\
\text { Mothers }\end{array}$ & $\therefore$ & $\begin{array}{r}89 \\
125\end{array}$ & $\begin{array}{l}6(6.7 \%) \\
5(4.0 \%)\end{array}$ & $\begin{array}{l}26(29 \cdot 2 \%) \\
14(11 \cdot 2 \%)\end{array}$ \\
\hline
\end{tabular}

TABLE v-Types of Criminal Offences in Index Group

\begin{tabular}{|c|c|c|}
\hline Criminal Offences & Fathers $(n=89)$ & Mothers $(n=125)$ \\
\hline $\begin{array}{l}\text { Theft, larceny, etc. } \\
\text { Crimes of violence } \\
\text { Serious sexual offences } . . \\
\text { Cruelty and neglect to children } \\
\text { Motoring and traffic offences } \\
\text { Drunk and disorderly } \\
\text { Breach of Probation Order }\end{array}$ & $\begin{array}{r}23 \\
8 \\
4 \\
1 \\
2 \\
1 \\
0\end{array}$ & $\begin{array}{r}13 \\
1 \\
0 \\
1 \\
0 \\
1 \\
1\end{array}$ \\
\hline
\end{tabular}

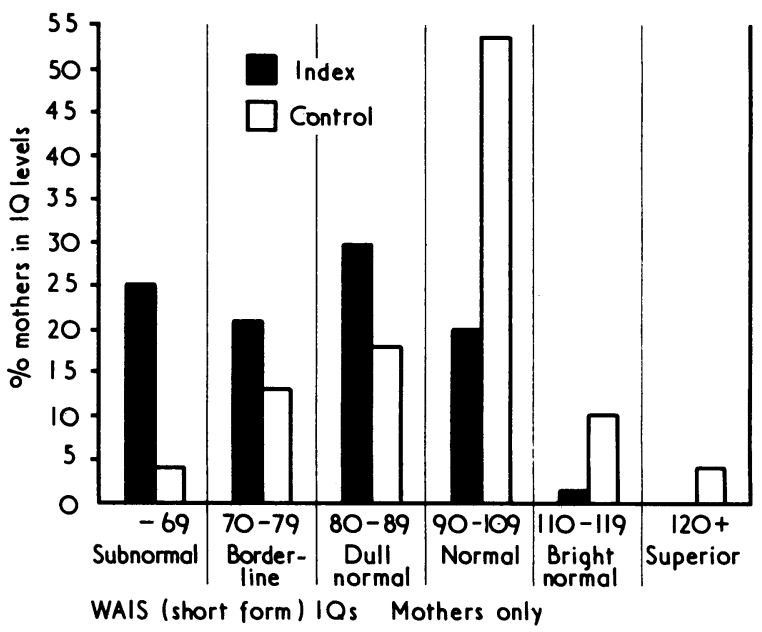

FIG. 2-Distribution of I.Q. in index and control mothers (Wechsler Adult Intelligence Scale).

\section{Discussion}

The young age of mothers closely compares with the age distribution described by other authors (Gil, 1968; Skinner and Castle, 1969). On average index mothers were aged $19 \cdot 7$ years at the birth of their first child. The compares strikingly with the national average age of 23.3 years (Registrar General, 1972). Even in the lowest social class the average was 22.6 years (Newson and Newson, 1965). Index mothers were thus nearly four years younger than the national average when they gave birth to their first infant. Taking into consideration our other observations that most battered babies were first or second born and that half were under 18 months old when battered it may be concluded that battering is associated with youthful parenthood. This argument is further exemplified by the infrequent occurrence of battering in older parents with large families observed in this and other series (Bennie and Sclare, 1969; Lukianowicz, 1971) and suggests that the risk of battering diminishes with parental age.

The parents in the present series were predominantly from the lower social classes. The association of low social class with battering parents has been commented on by several other workers (Young, 1964; Skinner and Castle, 1969). We found no support for the statement that all social classes were represented (Kempe, 1969). Of the index group $76 \%$ were from social class IV and V compared with only $32 \%$ in the Birmingham population (Birmingham Statistics, 1972). It may be argued that such a large discrepancy is due to the youthfulness of the parents and type of admission (emergency) of the children. Nevertheless, despite allowing for these important factors we 
found that the control group also contained $33 \%$ of social class IV and V. This strongly suggests that battering is mainly a lower social class phenomenon. Furthermore, as the criteria for referral of cases were medical we are reasonably confident that if more children from high social class families had been admitted with unexplained injuries then consultant paediatricians would have referred them.

Abnormality of personality was a significant finding among the parents of battered children. The less severe types of personality disturbance were more commonly found among the mothers, who in general had features of emotional immaturity and dependence. Many of these mothers had in addition little concept of appropriate child rearing practices. Battering may at best be regarded as an ineffectual method of controlling their child's behaviour. Techniques of teaching child rearing skills based realistically on their low intelligence should perhaps be explored further as a possible means of correcting such ineffectual parental care.

Among the fathers studied one third were psychopaths. The association of battering with psychopathy has been commented on before (Birrell and Birrell, 1968; Lukianowicz, 1971; Smith et al., 1973) but contrasts with Kempe's (1969) finding that psychopathy is a feature in only 2 or $3 \%$ of battering parents. Though most of these fathers had not killed their children it is disconcerting to observe that they share similar personality characteristics with a group of fathers who did kill their children (Oliver, personal communication, 1973; Scott, 1973).

Twenty-nine per cent. of the fathers had a criminal record. Though the follow-up period was brief, nevertheless $6.7 \%$ went on to commit subsequent crimes. Furthermore, though $19 \%$ of the children's siblings had been previously battered only $1 \%$ of parents had been charged with cruelty or neglect, highlighting the capriciousness of the legal system towards parents who batter babies. Criminality and recidivism, particularly if associated with a psychopathic personality, should caution against an optimistic outcome, and in our view invoking a care order is essential if further battering incidents are to be prevented. No association was found with alcoholism or drug addiction, which agrees with Steele and Pollock's (1968) findings but differs from those of Young (1964) and Gil (1968), who maintained that battering is precipitated by alcoholism.

We found that mothers were neurotic by three different measures. Fifty-eight per cent. were non-psychotically disturbed on the general health questionnaire, and $48 \%$ were diagnosed as neurotic at interview-the usual symptomatology being depression, anxiety, or a mixture of both. The diagnosis of neuroticism on the Eysenck Personality Inventory lends some support to the clinical findings of neurosis and the questionnaire results. One third (34\%) reported having an unhappy childhood. In general neurotic mothers (in contrast to psychopathic fathers) confessed to harming their children and expressed willingness to discuss their difficulties further. For this particular group of mothers the combination of symptomatic relief with a programme of social relearning conducted by skilled therapists seems to us to be far more beneficial than relying solely on programmes of "mothering" and other methods (Kempe and Helfer, 1972) that tend to reinforce their dependent behaviour.

Our findings confirm the view that only a minority of battering parents are psychotic (Steele and Pollock, 1968). The bizarre nature of the injuries inflicted by psychotic parents suggests that they form a separate subgroup among baby batterers whose management must differ accordingly.

\section{Conclusion}

Oliver and Cox (1973) showed that the tendency to perpetuate child abuse in successive generations is not diminished by supplying extensive medical and social help to battering parents. Furthermore, $60 \%$ of children who are returned home are rebattered (Skinner and Castle, 1969). While every effort must be made to rehabilitate battering parents this should not be at the expense of the safety of the child. In the light of our findings we believe that strong consideration should be given to permanent removal of children from parental care in those cases where after an overall psychiatric assessment the likelihood of parents responding to treatment is thought to be remote.

We are grateful to Mrs. Carol Smith, who helped with the psychological testing, and Mrs. J. Harold and Mrs. Irene Brown, of the Department of Medical Statistics, United Birmingham Hospitals, who helped with the statistical analysis. Professor W. H. Trethowan provided valuable criticism. We are also most grateful to Detective Chief Superintendent Harry Robinson for his ready help. The department of medical illustration of the Birmingham Children's Hospital provided the figures. We are especially grateful to the paediatricians who referred patients to us. Mrs. Sue Knight typed the manuscript. The study was supported by a grant from the Barrow and Geraldine Cadbury Trust.

\section{References}

American Psychiatric Association (1952). Diagnostic and Statistical Manual for Mental Disorders. Washington, D.C., A.P.A

Bennie, E. H., and Sclare, A. B. (1969). American fournal of Psychiatry, $125,975$.

Birrell, R. G., and Birrell, J. H. W. (1968). Medical Fournal of Australia, $2,1023$.

City of Birmingham (1972). Abstracts of Statistics (1970-1). Central Statistics Office, City of Birmingham.

Eysenck, H. J., and Eysenck, S. B. G. (1964). Manual of the Eysenck Personality Inventory. London, University of London Press.

Gibbens, T. C. N., and Walker, A. (1956). Cruel Parents. London, Institute for the Study and Treatment of Delinquency.

Gil, D. G. (1968). In Battered Child, ed. R. E. Helfer and H. Kempe. Chicago, University of Chicago Press.

Goldberg, D. P. (1972). Detection of Psychiatric Illness by Questionnaire. London, Oxford University Press.

Kempe, C. H. (1969). Hospital Practice, 44, 4.

Kempe, C. H., and Helfer, R. E. (1972). In Helping the Battered Child and His Family, ed. C. H. Kempe and R. E. Helfer. Oxford, Lippincott.

Lukianowicz, N. (1971). Psychiatria Clinica, 4, 257.

Newson, J., and Newson, E. (1965). Patterns of Infant Care in an Urban Community. London, Allen and Unwin. (Penguin Books, 1972.)

Oliver, J. E., and Cox, J. (1973). British fournal of Psychiatry, 123, 81. Registrar General (1972). Statistical Review of England and
Part 2. London, H.M.S.O.

Scott, P. D. (1973). Medicine, Science and the Law. 13, 197.
Skinner, A. E., and Castle, R. L. (1969). 78 Battered Children: A Retrospective Study. London, National Society for the Prevention of Cruelty
(196) to Children.

Smith, S. M., and Hanson, R. (1972). Postgraduate Medical fournal, 48, 382.

Smith, S. M., Honigsberger, L., and Smith, C. (1973). British Medical fournal, 3, 20.

Steele, B. F., and Pollock, C. B. (1968). In Battered Child. Ed, R. E. Helfer and $H$. Kempe. Chicago, University of Chicago Press.

Walton, H. J., and Presly, A. S. (1973). British fournal of Psychiatry, 122, 259.

Wechsler, D. (1955). Manual for the Wechsler Adult Intelligence Scale. New York, The Psychological Corporation.

Woolley, P. V., and Evans, W. A. (1955). Fournal of the American Medical Association, 158, 539 .

Association, 158, 539.
World Health Organization (1968). International Classification of Diseases. Geneva, W.H.O

Young, L. (1964). Wednesday's Children: A study of Child Neglect and Abuse. New York, McGraw-Hill. 